$\begin{array}{r}\text { Volume and Issues Obtainable at Center for Sustainability Research and Consultancy } \\ \text { Sustainable Business and Society in Emerging Economies } \\ \text { ISSN: 2708-2172 \& (E): 2708-2504 } \\ \text { Volume 3: Issue 1 March 2021 } \\ \text { CSRᄃ } \\ \text { Journal homepage: www.publishing.globalcsrc.org/sbsee } \\ \hline\end{array}$

\title{
Relationship Quality and Innovation Capacity of Micro Enterprises: A Single Case Study in the Traditional Food Sector
}

\author{
*Alexander Joseph Ibnu Wibowo, Faculty of Business and Economics, Universitas Prasetiya Mulya, \\ Jakarta, Indonesia \\ Suherman Widjaja, Faculty of Business and Economics, Universitas Prasetiya Mulya, Jakarta, \\ Indonesia \\ Bernardinus Realino Yudianto, Faculty of Business and Economics, Universitas Prasetiya Mulya, \\ Jakarta, Indonesia
}

*Corresponding author's email address: ibnu.wibowo@pmbs.ac.id

\begin{tabular}{l}
\hline ARTICLE DETAILS \\
\hline History \\
Revised format: Feb 2021 \\
Available Online: Mar 2021 \\
\hline
\end{tabular}

Keywords

Innovation Capacity, Relationship Quality, Case Study, Traditional Food, Marketing

\section{JEL Classification}

M31, O31

\section{ABSTRACT}

Purpose: This study aims to analyze the innovation capacity and relationship quality of micro-enterprises with its stakeholders.

Design/Methodology/Approach: This is an exploratory and singlecase study that uses an in-depth interview with the owner of one traditional food micro-enterprise (TFME) in Yogyakarta City (Daerah Istimewa Yogyakarta Province, Indonesia).

Findings: The results determined that there are four types of relationships between a TFME and its stakeholders: supplier, internal, customer, and lateral partnerships. We further identify antecedents of relationship quality: opportunistic behavior, reputation, customer orientation, relationship orientation, conflicts, product quality, and knowledge and skills. The research further found that conflicts, relationship quality, product quality, knowledge and skills, and owner's age can affect the innovation capacity of a TFME.

Implications/Originality/Value: Theoretically, the findings provide support for the development of relationship marketing theory. Practically, this study is valuable for TFMEs to build relationship quality with stakeholders and innovation capacity.

(C) 2021 The authors, under a Creative Commons AttributionNonCommercial- 4.0

Recommended citation: Wibowo, A. J. I., Widjaja, S. and Yudianto, B. R. (2021). Relationship Quality and Innovation Capacity of Micro-Enterprises: A Single Case Study in the Traditional Food Sector. Sustainable Business and Society in Emerging Economies, 3 (1), 25-33.

\section{Introduction}

According to the World Economic Forum (WEF), Indonesia has a more efficiency-driven economy, which ranks the country 50th out of 141 countries worldwide in the Global Competitiveness Index 2019 Rankings. The weakness of the pillars of innovation in Indonesia, including the capacity for innovation, is thought to be one of the primary causes of Indonesia's low rankings in the Global Competitiveness Index (WEF, 2019). In Indonesia, micro-, small-, and medium-sized enterprises (MSMEs) are relatively vulnerable to competition (Wibowo, 2019a). According to Tambunan (2011), Indonesian MSMEs, 
which includes energy, information, infrastructure, market environment, inflation, and taxation, face four main obstacles: capital, technology, skills, marketing, and raw materials. Indeed, Irjayanti and Aziz (2012) found 10 factors that can inhibit the development of Indonesian MSMEs: competition restrictions, financial access, fuel tariffs, technology, inefficient production costs, economic factors, management abilities, processes, limited sales, and raw materials. Indonesian MSMEs should increase their innovation capacity to overcome these obstacles. They also need to improve the quality of the relationships with their business partners to encourage greater innovation capacity. In terms of this capacity, Novani, Putro, and Hermawan (2014) noted the importance of maintaining a sustainable relationship with all stakeholders during the actual value co-creation process.

Therefore, Indonesia must encourage more innovation to increase competitiveness. One way is to increase the competitiveness of micro-businesses is through sustainable innovation. In 2018, the number of micro-enterprises in Indonesia reached 63 million by a workforce of around 107 million people (http://www.depkop.go.id, accessed September 1, 2020). Micro-enterprises in the traditional food sector thus require serious attention. Based on the above explanations, it is urgent to conduct a study examining the relationship quality, innovation capacity, and linkage between relationship quality and innovation capacity in the context of Indonesia's microsized traditional food enterprises (TFMEs). Theoretically, we hope this research can enrich the theory of relationship marketing and innovation in the local food sector.

\section{Literature Review}

Relationship quality is a concept discussed extensively in relationship marketing theory. This concept emphasizes the importance of building long-term and mutually beneficial relationships with customers. Companies need to use relationship quality to reduce transaction costs or the uncertainty about future transactions, thereby ensuring the sustainability of their system operations (Yu \& Tung, 2013). Some literature, however, does not offer a consistent enough definition of the concept of relationship quality (Yu et al., 2013; Akbar \& Wibowo, 2018). Nonetheless, many researchers have linked satisfaction and trust as prominent indicators of relationship quality (Shamdasani \& Balakrishnan, 2000; HenningThurau, Langer, \& Hansen, 2001; Wibowo, 2009). Further, Smith (1998) and Kumar, Scheer, and Steenkamp (1995) stated that relationship quality contains at least three dimensions: satisfaction, trust, and commitment. On the other hand, Wu, Weng, and Huang (2012), in a study on the context of supply chain partnerships, found that the higher the level of trust between partners, the better the partners were able to direct the interaction between those partners. In this case, trust was the main factor and played a significant role in influencing supply chain partnerships effectively (Wibowo, 2013). Besides, the trust supports positive collaboration (Wu et al., 2012; Pesamaa \& Hair Jr, 2007; Terawatanavong \& Quazi, 2006; Fynes, Voss, \& Burca, 2005; Leonidou, Palihawadana, \& Theodosiou, 2006).

Innovation refers to a company's capacity to engage in the creation of new ideas, experimentation, and research and development activities that produce novel outputs and acitivities at a competing cost (Hadjimanolis, 2000; Hult, Hurley, \& Knight, 2004; Chadee \& Roxas, 2013). If a company utilizes the right mode of communication, then it produces positive innovation capacity or innovativeness (Lee \& Tsai, 2005). Particular strategies, such as eco-design, reverse logistics, recuperation of waste, or the use of cleaner raw materials or recycled products, can direct a company to recognize its innovation capacity (Fraj-Andrés, Martinez-Salinas, \& Matute-Vallej, 2009). Besides, corporate innovation and competence can contribute to improved operational performance (Venkatraman \& Ramanujam, 1986; Zhang, 2000; Fraj-Andrés et al., 2009). Rampant corruption in companies can have a significant impact on both innovation ability and achievement (Chadee et al., 2013). Strictly speaking, Lee and Tsai (2005) proved the impacts of innovativeness on business performance for 700 service and manufacturing companies in Taiwan.

Gellynck, Kühne, and Weaver (2011) surveyed 90 traditional food chains that involved 270 companies from three countries in Europe (Belgium, Hungary, and Italy). The authors found the quality of chain 
relationships to be a notable factor in motivating innovation. Policies that encourage companies to build those strong relationships can accelerate innovation. Further, Murat Ar and Baki's (2011) study on 270 managers of small and medium enterprises in Turkey revealed the influence of supplier relationships on product innovation. Similarly, organizational collaboration can have an impact on process innovation. Innovativeness in a collaborative interaction depends on knowledge sharing (Calantone, Cavusgil, \& Zhao, 2002; Panayides \& So, 2005; Wibowo, 2019b); further, due to fears of opportunistic behavior, companies may be reluctant to share their knowledge with partners, which can damage innovation (Steinicke, Wallenburg, \& Schmoltzi, 2012). This aspect suggests that opportunistic behaviors can have an impact on the ability of partners to innovate. In other words, opportunism can reduce a company's innovation capacity.

\section{Methodology}

A qualitative research design was utilized for this study, which seeks to capture meaning in the relationship phenomenon between TFME and its stakeholders as well as the nature of that relationship to the TFME's innovation capacity. In this exploratory study, we wanted to understand how a TFME's owner translates his/her experiences and how he/she builds her world (Merriam, 2009). This study also seeks to describe, understand, and interpret the relationship phenomenon based on the different realities that exist in the microscale traditional food industry in Indonesia. The research also seeks to obtain empirical data to build the concept of relationship quality and the innovation capacity of a TFME.

The study was conducted on a TFME, namely, "Arem-arem Bu Nyoto (AABN)," which is located in Yogyakarta City (Daerah Istimewa Yogyakarta Province, Indonesia). The research participant was the owner of AABN, Mrs. Nyoto. Data collection was undertaken using unstructured in-depth interviews. This particular interview structure requires open questions, is flexible, and extracts a range of information from the participant. The questions address the participant's experience and behaviors as well as opinions and values, feelings, and knowledge. The probing technique is widely applied to follow up on the participant's answers. AABN sells Indonesian traditional foods called "arem-arem," which is a rice roll that contains vegetables or fried sambal wrapped in banana leaves.

This study also used inductive analysis strategies and a conversation approach, both of which are suitable for analyzing data in interpretative qualitative studies. Specifically, the two strategies or techniques for analyzing qualitative data are narrative analysis and case study. The essence of narrative analysis is to examine the way humans experience the world (Connelly \& Clandinin, 1990), i.e., how the participant (owner) experiences and interprets his/her relationship and its quality with stakeholders and innovation capacity of the TFME. This particular narrative analysis emphasized the AABN's owner stories. Further, the collected data were analyzed using relationship marketing theory and its perspectives.

\section{Results}

Based on the in-depth interview with the TFME's owner, four types of relationships are determined to exist between TFME and its stakeholders: supplier, internal, buyer, and lateral partnership. Supplier partnership is a type of relationship established among TFME and its suppliers of raw materials. The internal partnership is a relationship between each component in the TFME's organization, such as the relationship between leaders and employees, inter-departmental functional relationships, and the relationships between business units. Customer partnership includes the relationship between TFME and its current customers, new customers, and potential customers. The lateral partnership shows the relationship between TFME and its competitors, profit organizations, nonprofit organizations, neighbors, and the government.

Generally, the participant has one supplier for each subscribed raw material. The participant usually does not change suppliers. Every year, she (the participant) receives gifts from several suppliers. She further believes that the suppliers do not cheat her because she has subscribed for a long time and has 
never been deceived by them. Even so, suppliers often send goods first, which are paid for later. Therefore, she is willing to agree to price fluctuations incurred by her suppliers. The following is her reply:

\begin{abstract}
I have one permanent supplier. I have purchased from the same supplier, and every year I receive gifts from the supplier. I never move to other places. I never protest the pricing policy and always comply with it. If the rice quality is a little ad, I immediately ask for an exchange. I do not mind paying extra money as long as the rice quality is good. The supplier has known me for years and knows my traits regarding rice quality. So, I never change suppliers because they have supplied rice to me for decades.
\end{abstract}

The relationship between the family of the TFME's owner determines the degree of business sustainability. This study found that family members can play an essential role in creating business opportunities. Good relationships among the owner's family members are useful to develop promotion. For example, the owner of AABN, Mrs. Nyoto, can get a purchase order through her son (orders done by the company where her son works). However, the owner's divorce had an impact on the business. Her husband used to play a decisive role because he was able to motivate and provide support when business pressure and challenges appeared.

The study also found that the relationship quality between AABN's owner and the employees determined both business activities and performance. Good relationship quality is usually able to maintain a great owner-employee relationship in the long run, even if an employee leaves. According to the participant, however, she had unpleasant experiences with her former employees:

When hiring helpers, they may resign and start their own arem-arem business. They would sell the products to some bakul (traders) who have become my customers. It could cause me to become at odds with them. It made me unhappy because I could quarrel with them. Until now, they continued to sell arem-arem. They work for me to steal the secret recipe for my arem-arem...Currently, I only employ neighbors as my helpers.

The relationship quality between the TFME and its customers was demonstrated by how much customers trusted the TFME, which can be indicated by large and repeat orders. The relationship quality can be realized by the willingness of TFME to help its customers financially. For example, TFME is willing to help customers by processing their raw materials into finished goods. The quality of the relationship between customers and TFME can also be seen in customer behaviors when taking the initiative or showing an intention to establish other relationships in the future. For example, the customer takes the initiative to request the TFME's contact number as the means of communication for the next order or purchase. Even so, the TFME does not always fulfill customer orders. The participant usually will refuse orders from customers who failed to pay off their previous purchases.

Besides, the TFME was also willing to accept down-payments from customers and cover the production costs for ordering goods for them. Although there is occasionally no written agreement, the participants felt confident that the customer would pay off the remaining payment and not cheat the owner because the participant trusted the customer. In dealing with customers, the business owner does not merely take into account the profit aspect. The owner is willing to make less profit because she also considers the conditions or difficulties of her customers. That is, the owner examines affections as central importance. Moreover, the owner is willing to bear losses over the short-term to establish lasting relationships with customers and create repeat purchases in the future and thus achieve long-term benefits.

However, the business owner can and does show opportunistic behavior under certain conditions. This is visible when the owner's actions harm customers for her benefit. To support this action, the owner hides opportunistic acts from the customers. Generally, the owner carried out this kind of behavior when she feels it is urgent. In this circumstance, she feels anxious that customers may become aware of the action:

I once received an order of 2000 arem-arems. As planned, I hired two people to handle this order. However, in the morning, when the order was due, we could not produce the requested number of arem-arem. To cover the shortage, 
I bought arem-arems made by other sellers. I was worried and hoped that the customers would never have known. Usually, I can produce the number of arem-arems requested in the orders. The middle of the year during the student orientation period (in new student admission) is the time for the high demand of arem-arem. Sometimes I add aremarem produced from other sellers to cover the shortage. I am worried that customers will know because my aremarem may taste differently from the arem-arems made by other sellers.

The TFME is a small business located in a residential area. Therefore, there is a relatively close relationship between TFME and its residents or neighbors. This close relationship is visible in the ongoing willingness of the enterprise and the community to help each other. For example, when receiving orders that total thousands of arem-arems, the owner usually hires neighbors as temporary employees, especially unemployed neighbors.

The participant mentioned the lack of government roles in the traditional food industry, e.g., government has not provided any training assistance for a long time to the TFME. The quality of the relationship between the government and TFME is considered unfavorable, probably because of the weak personal relationships between the TFME's owner and current village officials. One measure of the strength of these ties is the involvement of the TFME owner in different government-organized activities. Successful relationships between the government and TFME can encourage TFME to support various government activities, especially in empowering other TFMEs. The participant further conveyed that she has not been engaged in training programs for small businesses with the local government for a long time.

This study also found that the participant had not established any intensive relationship with the banking sector. She does not rely on banks to obtain business capital, so she does not have loans with the bank. The owner has savings that can be utilized for business development, such as buying land and a house. On the other hand, TFME owners do establish mutually beneficial relationships with competitors. The TFME owners invited competitors to collaborate with and help solve business problems. For example, when the price of chicken is high (reaching IDR 40,000 per head), the arem-arem price will also become more expensive due to higher production costs. For this reason, the TFME's owner will order aremarems from other sellers. Figure 1 displays the types of relationships that exist between the TFME and its stakeholders.

The participant understood the importance of differentiation. As such, she attempted various innovations by creating differences between her products and the competitors'. She realized that unique and superior products will attract consumers. This view supports the decision to make products widely known. She also innovated prices to create a distinction to reach different and broader consumer segments. The idea of price differentiation was her own. She received no government assistance. Likewise, various ideas for product innovation thus far come from business experience. The participant experiments directly by using her own business to produce and deliver high-quality products that consumers like. The following quote explains:

In general, buyers are looking for arem-arem because of the savory taste. I use Cisadane rice, while other sellers use Raskin (rice for poor people), C4, and others (bad quality rice). This rice is quite expensive, but it is easier to deal with it. When I let it cool, it does not become stiff. The Cisadane rice looks limp, making the wrapping process easier. During the rainy season, kluthuk banana leaves ("kluthuk" is a type of banana) are difficult to obtain and expensive. If you do not use these types of leaves, then the rice in arem-arem becomes red and ugly. I am using ripe coconut. The coconut milk is thick and very tasteful. So as not to taste fishy, I boiled the chicken, then I throw away the water. Next, my chicken is fried and cut into small pieces, and then the chicken is cooked until the meat is kalis (smooth) and clean. 
Figure 1: Different types of relationships existing betweeen TFME and its stakeholders

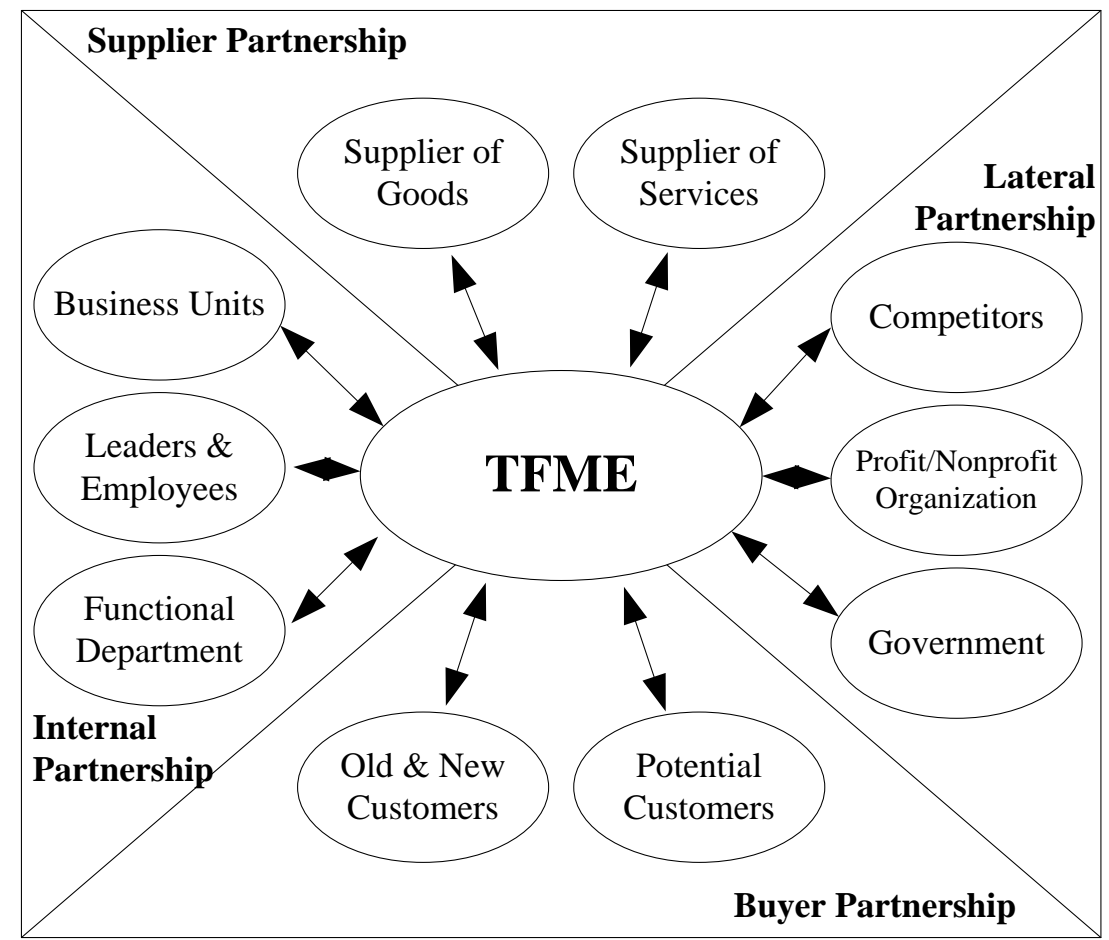

However, the innovations of this business owner not only include product innovation but also process innovation. She said that, in the past, she cooked on an earthen stove over firewood. Then, she used timber sawdust and gas; now she cooks using a gas stove. Besides, she holds firm to her business ethics whenever innovating. In general, she understands the importance of maintaining customer trust and customer welfare by always providing high-quality products to keep customers interested and not harm them. Even so, during any hectic conditions, she also demonstrated opportunistic behavior:

Some buyers asked me the reason why my arem-arems are not durable, even though they are made on the same day, while other arem-arems remain good, even though produced the day before. Other arem-arems have been mixed with borax (artificial preservative). Some complain why arem-arem is rotten in the morning. After checking, these arem-arems were not made by me. If a buyer is ordering arem-arem containing fish, then I will fill it with fish entirely and not mix it with other ingredients. Other producers may put in a little fish and mix it with other materials, such as tempeh (tempeh made from soybeans processed with yeast).

Based on these in-depth interviews with the participant who owns the TFME, we found a strong linkage between relationship quality and innovation capacity. Good relationship quality that exists between the business owner and her suppliers have a direct impact on the quality and sustainability of the raw material supply used for the production process. Therefore, if the supplier is not willing to replace (exchange) raw materials where the quality is not as expected, it will hamper the innovation process during production. Good relationships with suppliers help a business obtain the right raw materials that will support product innovation processes. As explained earlier, the business owner needs specific raw materials to support creativity and innovation and create products that are different, unique, and superior to attract more consumers.

A good relationship among the owner's family members is crucial for business continuity. Family members play a significant role as a source of information when identifying business opportunities and product innovation. For example, the business owner's son working in a company can provide useful information for new business opportunities from his colleagues. Family members can also play a role as motivators when running the business. Family member support has a definite impact on the innovation process and business sustainability. Conversely, any strained relationship between family members can hinder business continuity and the process of innovation, as with this owner's divorce case. 


\section{Discussion}

As described in the previous section, the opportunistic behavior of the TFME's owner is visible in the actions that may harm stakeholders to obtain a unilateral profit of the owner in the short term. If customers learned that the owner deceived them, they would have felt disappointed. They would have felt dissatisfied with the relationship, which they very likely would break. The owner's actions could damage the relationship quality with customers in the long term. Therefore, the business owner's innovation capability cannot be integrated with customer resources. Customers will not be willing to share information and knowledge with the business owner for any co-innovation. The low relationship quality with primary stakeholders can evoke conflict with other stakeholders. Likewise, conflict with stakeholders can result in a poor relationship with them. Further, this conflict directly affects innovation capacity. That capacity to innovate will not be optimal without involving both "good" competitors and the surrounding community.

Relationship quality can also have an impact on product quality. Trusted suppliers typically establish relationships by selling qualified raw materials to their buyers. Furthermore, high-quality raw materials will produce valuable finished products. That product is preferred by customers so that they can increase sales. The implication is that this issue can also affect the relationship quality between the business owner and suppliers. Quality of raw materials determines the innovation process. Besides, the ability to innovate can specify the quality of the finished products. An owner with a lot of experience and knowledge should have greater innovation capacities than those who lack that experience and knowledge. Therefore, innovation capacity determines product quality. Further still, product quality can encourage business sustainability because consumers will have great demand for these quality products.

The business owner's knowledge and skills play a significant role in encouraging innovation capabilities. The owner cannot innovate optimally without adequate knowledge and skills. These resources can be drawn from experiences and relationships with stakeholders and can play a mediating role. First, stakeholders can influence the connection between relationship quality and innovation capacity, as in a business's understanding of the importance of business ethics, which can further strengthen the influence of relationship quality on innovation capacity. Conversely, weak business ethics can weaken the impact of a relationship quality on innovation capacity. Second, such knowledge and skills can also influence the relationship between innovation capacity and business strategy. For example, the owner's understanding of the importance of technology can further strengthen the influence of innovation capacity on business strategy. Conversely, the owner's lack of comprehension of the significance of technology can weaken the impact of innovation capacity on the business strategy.

The owner's age and business risk can also act as moderating variables. Age can influence the relationship between innovation capacity and business strategy and sustainability. Business people who are too old or too young, for example, can further weaken the influence of innovation capacity on the implementation of business strategies and overall business sustainability. Age can also determine the ability to innovate as a business. Generally, business people who are too old or too young also will have physical and mental limitations, so the ability to innovate then further decreases. These business risks can affect the relationship between innovation capacity and business strategy and business continuity. High-risk businesses, for example, should strengthen the influence of innovation capacity on both business strategy implementation and business sustainability.

\section{Conclusion}

This study seeks to identify the relationship quality between the TFME and its stakeholders and examined the TFME's innovation capacity. Specifically, the various antecedents and consequences of its relationship quality and innovation capacity were examined. In summary, the relationship between the TFME owner and the stakeholders can be divided into four types: supplier relationships, internal relationships, customer relationships, and lateral relationships. 
We further identified several factors that determine the relationship quality: opportunistic behavior, reputation, customer orientation, relationship orientation, conflict, product quality, and knowledge and skills. We also determined that the quality of relationships can influence key factors for TFME, i.e., innovation capacity, business strategy, business sustainability, conflict, product quality, knowledge and skills, experience, and relationship orientation.

\section{References}

Akbar, T. F., \& Wibowo, A. J. I. (2018). Relationship quality with global business partners and global business performance. Asian Journal of Entrepreneurship and Family Business, 2(2), 93-106.

Badan Pusat Statistik (2016). Jumlah perusahaan industri mikro dan kecil menurut 2-digit KBLI, 20102015. Retrieved from https://www.bps.go.id/dynamictable/2015/11/24/1011/jumlah-perusahaanindustri-mikro-dan-kecil-menurut-2-digit-kbli-2010-2015.html.

Calantone, R., Cavusgil, S., \& Zhao, Y. (2002). Learning orientation, firm innovation capability, and firm performance. Industrial Marketing Management, 31(6), 515-24.

Chadee, D., \& Roxas, B. (2013). Institutional environment, innovation capacity, and firm performance in Russia. Critical Perspectives on International Business, 9(1/2), 19-39.

Connelly, F. M., \& Clandinin, D. J. (1990). Stories of experience and narrative inquiry. Educational Reearcher, 19(2), 1-14.

Fraj-Andrés, E., Martinez-Salinas, E., \& Matute-Vallej, J. (2009). A multidimensional approach to the influence of environmental marketing and orientation on the firm's organizational performance. Journal of Business Ethics, 88, 263-286.

Fynes, B., Voss, C., \& de Burca, S. (2005). The impact of supply chain relationship dynamics on manufacturing performance. International Journal of Operations \& Production Management, 25(1), 6-19.

Gellynck, X., Kühne, B., \& Weaver, R. D. (2011). Relationship quality and the innovation capacity of chains: The case of the traditional food sector in the EU. International Journal of Food System Dynamics, 2(1), 1-22.

Hadjimanolis, A. (2000). A resource-based view of innovativeness in small firms. Technology Analysis \& Strategic Management, 12(2), 263-81.

Hennig-Thurau, T., Langer, M. F., \& Hansen, U. (2001). Modeling and managing student loyalty. An approach based on the concept of relationship quality. Journal of Service Research, 3(4), 331344.

Hult, G. T., Hurley, R., \& Knight, G. (2004). Innovativeness: Its antecedents and impact on business performance. Industrial Marketing Management, 33(5), 429-38.

Irjayanti, M., \& Azis, A. M. (2012). Barrier factors and potential solutions for Indonesian SMEs. International Conference on Small and Medium Enterprises Development with a Theme (ICSMED 2012). Procedia Economics and Finance, 4, 3-12.

Kumar, N., Scheer, L. K., \& Steenkamp, J. (1995). The effects of perceived interdependence on dealer attitudes. Journal of Marketing Research, 32(3), 348-356.

Lee, T-S., \& Tsai, H-J. (2005). The effects of business operation mode on market orientation, learning orientation and innovativeness. Industrial Management \& Data Systems, 105(3), 325-348.

Leonidou, L. C., Palihawadana, D., \& Theodosiou, M. (2006). An integrated model of the behavioural dimensions of industrial buyer-seller relationships. European Journal of Marketing, 40(1/2), $145-173$.

Merriam, S. B. (2009). Qualitative research. A guide to design and implementation. San Francisco, CA: John Wiley \& Sons.

Ministry of Cooperatives and SMEs of The Republic of Indonesia (2018). Perkembangan data usaha mikro, kecil, menengah (UMKM) dan usaha besar. Retrieved from http://www.depkop.go.id/uploads/laporan/1580223129_PERKEMBANGAN\%20DATA\%20US AHA\%20MIKRO,\%20KECIL,\%20MENENGAH\%20(UMKM)\%20DAN\%20USAHA\%20BES 
AR\%20(UB)\%20TAHUN\%202017\%20-\%202018.pdf. Accessed September 1, 2020.

Murat Ar, I., \& Baki, B. (2011). Antecedents and performance impacts of product versus process innovation. Empirical evidence from SMEs located in Turkish science and technology parks. European Journal of Innovation Management, 14(2), 172-206.

Novani, S., Putro, U. S., \& Hermawan, P. (2014). An application of soft system methodology in batik industrial cluster Solo by using service system science perspective. The 5th Indonesia International Conference on Innovation, Entrepreneurship, and Small Business (IICIES 2013). Procedia-Social and Behavioral Sciences, 115, 324-331.

Panayides, P., \& So, M. (2005). Logistics service provider - client relationships. Transportation Research Part E: Logistics and Transportation Review, 41(3), 179-200.

Pesamaa, O., \& Hair Jr, J. F. (2007). More than friendship is required: An empirical test of cooperative firm strategies. Management Decision, 45(3), 602-615.

Shamdasani, P. N., \& Balakrishnan, A. A. (2000). Determinants of relationship quality and loyalty in personalized services. Asia Pacific Journal of Management, 17(3), 399-422.

Smith, J. B. (1998). Buyer-seller relationships: Similarity, relationship management, and quality. Psychology and Marketing, 15(1), 3-21.

Steinicke, S., Wallenburg, C. M., \& Schmoltzi, C. (2012). Governing for innovation in horizontal service cooperations. Journal of Service Management, 23(2), 279-302.

Tambunan, T. T. H. (2011), Development of small and medium enterprises in a developing country. Journal of Enterprising Communities: People and Places in the Global Economy, 5(1), 68-82.

Terawatanavong, C., \& Quazi, A. (2006). Conceptualising the link between national cultural dimensions and B2B relationships. Asia Pacific Journal of Marketing and Logistics, 18(3), 173-183.

Venkatraman, N., \& Ramanujam, V. (1986). Measurement of business performance in strategy research: A comparison of approaches. Academy of Management Review, 11(4), 801-814.

Wibowo, A. J. I. (2009). Pengaruh manfaat dan kualitas hubungan relasional terhadap hasil pemasaran relasional: Sebuah studi terhadap layanan suratkabar. Jurnal Administrasi Bisnis, 5(1), 70-90.

Wibowo, A. J. I. (2013). Perilaku oportunistik dalam hubungan kemitraan (partnership): Sebuah analisis konseptual dengan menggunakan model IGMOB. Jurnal Bina Ekonomi, 17(2), 86-108.

Wibowo, A.J.I. (2019a). Analisis industri makanan tradisional berbasis concentration ratio, herfindahlhirschman index, dan minimum efficient scale. Inovasi, 15(1), 26-43.

Wibowo, A.J.I. (2019b). Finance-seeking behaviour of small and medium-sized enterprises: An exploratory study. AdBispreneur: Jurnal Pemikiran dan Penelitian Administrasi Bisnis dan Kewirausahaan, 4(1), 45-55.

World Economic Forum (2019). The global competitiveness report 2019. World economic forum Geneva. Retrieved from http://www3.weforum.org/docs/WEF_TheGlobalCompetitivenessReport2019.pdf

Wu, M.-Y., Weng, Y.-C., \& Huang, I.-C. (2012). A study of supply chain partnerships based on the commitment-trust theory. Asia Pacific Journal of Marketing and Logistics, 24(4), 690-707.

Yu, T-W., \& Tung, F-C. (2013). Investigating effects of relationship marketing types in life insurers in Taiwan. Managing Service Quality, 23(2), 111-130.

Zhang, Z. (2000). Developing a model of quality management methods and evaluating their effects on business performance. Total Quality Management, 11(1), 129-138. 